\title{
A case of generalized edema associated with risperidone monotherapy
}

\author{
Risperidon Tedavisi ile ilişkili bir yaygın ödem olgusu
}

\author{
Omer Asan1, Elif Tatlidil Yaylaci², Erol Göka ${ }^{3}$ \\ ${ }^{1}$ Uzm. Dr., Sakarya University Training and Research Hospital, Department of Psychiatry, Türkiye \\ https://orcid.org/0000-0002-4340-4553 \\ 2Doç. Dr., Kocaeli University Medical Faculty, Department of Psychiatry, Türkiye \\ https://orcid.org/0000-0002-1157-7409 \\ 3 Prof. Dr., Ankara Numune Training and Research Hospital, Department of Psychiatry, Türkiye \\ https://orcid.org/0000-0001-7066-2817
}

\section{SUMMARY}

Risperidone is a second-generation antipsychotic agent, widely used in psychiatric disorders like schizophrenia, bipolar disorder, and aggression. Edema has been reported as a side effect of risperidone in a few case reports in the literature. In most of these cases, another drug was combined with risperidone and edema was located in a specific zone. Here we aimed to report a case of generalized edema due to risperidone oral monotherapy and reviewed the relevant literature.

Key Words: Adverse effect, Edema, Risperidone, Schizophrenia

\section{ÖZET}

Risperidon şizofreni, bipolar bozukluk, agresyon gibi psikiyatrik bozukluklarda yaygın olarak kullanılan bir ikinci jenerasyon antipsikotik ilaçtır. Ödem, literatürde risperidonun bir yan etkisi olarak az sayıda vakada bildirilmiştir. Bu vakaların çoğunda risperidon bir başka ilaçla kombine kullanılmıştır ve ödem yan etkisi vücudun belirli bir bölgesinde lokalizedir. Bu yazıda tek başına oral risperidon kullanımına bağlı gelişen bir yaygın ödem olgusunu sunmayı ve bu konuyla ilgili literatürü gözden geçirmeyi amaçladık.

Anahtar Sözcükler: Yan etki, Ödem, Risperidon, Şizofreni, 


\section{TO THE EDITOR}

Risperidone, a benzisoxazole derivative, is a second-generation antipsychotic that binds to serotonin type 2 and a1-adrenergic receptors with high affinity and causes antagonism at these receptor sites (1). Risperidone has been proven to be effective in psychotic disorders, bipolar disorder, aggression, and several other psychiatric disorders. The most common side effects of risperidone use are extrapyramidal symptoms, dizziness, hyperkinesias, somnolence, and nausea (2). However, after reviewing the literature on the complications of risperidone therapy, we found few case reports documenting edematous adverse effects of risperidone without combined with other agents. In this paper, we reported a case of generalized edema associated with risperidone treatment and reviewed the literature about this side effect.

A 36-year old woman who had been treated for schizophrenia for three years was admitted to our inpatient clinic for the second time with complaints of suspiciousness, furious behavior, and social avoidance. Her first admission to psychiatry was three years ago with the same complaints. She was treated in our inpatient unit with the diagnosis of schizophrenia. After her discharge, she had used paliperidone palmitate $100 \mathrm{mg}$ i.m. inj./month for one year and then gave up treatment. Her mental status was stable for one-year-period, noncompliance with the treatment after this time resulted in the appearance of psychotic symptoms. She did not experience any adverse effect except mild akathisia, which was treated with propranolol 40 $\mathrm{mg} /$ day. There was no history of any other psychiatric medication. At her second admission, risperidone $4 \mathrm{mg} /$ day treatment was initialized. At the second day of the risperidone treatment, she complained of swelling in her feet and hands. The swelling in her hands and feet increased day to day and also swelling in pretibial and periorbital zone bilaterally occurred. She didn't have a history of edema before. She did not use any other drug, vitamin, and supplements for last month. The results of a complete blood cell count, serum electrolytes, protein, albumin, renal function, liver function, thyroid function, C3, C4, IgE, IgM, IgG, serum and urine osmolarity, urinalysis, pregnancy test, chest radiography, and electrocardiogram did not explain the edema. The echocardiography showed an ejection fraction of $70 \%$ which implicates normal contractile function with normal cardiac valves. After cardiology, internal medicine and cardiovascular surgery consultations performed, edema considered as a side effect of risperidone treatment. After cessation of risperidone treatment, the edema decreased day by day and resolved spontaneously after six days. Aripiprazole $10 \mathrm{mg} /$ day treatment initialized for her psychotic symptoms, and after 14 days edema did not recur. We performed Naranjo Adverse Drug Reaction Scale, given a score of 7, that means a probable association between edema and risperidone treatment (3).

The actual mechanism of edema due to risperidone is still unclear. However, several possible underlying mechanisms such as allergic reactions, supersensitivity of receptors and complex drug interactions have been put forth. Firstly, edema may occur as a result of vasodilatation and a decrease in vascular resistance secondary to the blockade of a1 receptors by risperidone (4). Risperidone may induce the 5-HT receptor blockade which can potentially increase the plasma cyclic adenosine monophosphate levels that relax the vascular smooth muscle (5). The dopaminergic blockade can alter the renal regulation of electrolytes, which also may play a role in the development of edema (6). Also, several probable mechanisms may be involved in the onset of risperidone-induced edema such as the allergic reactions, receptor supersensitivity and drug interactions (7). The allergic reactions may be caused by mast cell degranulation or activation of the kallikrein-kinin cascade (8). C4$\mathrm{C} 2$ activation with previously low $\mathrm{c} 1$ inhibitor activity has been reported in a case, and Type- 1 and Type 4 allergic reactions in another patient $(1,9)$.

A review of the literature on edema secondary to risperidone indicated that in most cases, risperidone was used in combination with other psychotropic agents, including valproate, benzodiazepines, and dopamine receptor antagonists. The complex interaction between risperidone and other psychotropic drugs may have contributed to edema in these reported cases. Some cases documented an allergic reaction to risperidone resulting with edema and in another case edema was a side effect of parenteral risperidone treatment $(9,10)$. Also in 
a case, it is reported that the side effect was dependent on the drug dose (11).

In our case, there wasn't any drug interaction, and the edema was not secondary to an allergic reaction or another medical condition. The onset of the edema after the use of the medication and the disappearance after the withdrawal of the medication suggest that edema was a side effect of risperidone. The other important point about this case is that edema was located at different zones (periorbital, pretibial, pedal, hands), in most of the reported cases the edema was located at one region like pretibial, pedal, periorbital zone $(6,11,12)$. This case is also of importance as it demonstrates an adverse effect that had not occurred with the previous paliperidone treatment which is an active metabolite of risperidone with similar clinical efficiency.

The discontinuation and changing of the suspected drug with another agent is the first step in the treatment of edema secondary to risperidone. If the drug is indispensable for the patient, reducing the dose and observing until edema improves would be an appropriate choice. Also adding a diuretic agent may be effective (12).

As a result, edema is a rare but serious side effect of risperidone. This side effect may be dependent to drug dose, but also may occur with a small dose. It may affect the patient's drug maintenance negatively. Despite the low incidence, this side effect should always be taken into consideration by the clinicians. There is a need for future studies investigating the mechanism and incidence of this side effect.

Correspondence address: Uzm. Dr. Ömer Asan, Sakarya University Training and Research Hospital, Department of Psychiatry, Sakarya, Türkiye omerasan@hotmail.com

\section{REFERENCES}

1. Tamam L, Ozpoyraz N, Unal M. Oedema associated with risperidone. Clin Drug Invest 2002; 22:411-414.

2. Gunes F, Batgi H, Akbal A, Canatan T. Angioedema - an unusual serious side effect of risperidone injection. Clin Toxicol (Phila) 2013; 51:122-123.

3. Naranjo CA, Busto U, Sellers EM, Sandor P, Ruiz I, Roberts EA, Greenblatt DJ. A model for estimating the probability of adverse drug reactions. Clin Pharmacol Ther 1981; 30:239-245.

4. Yang HN, Cheng YM. Peripheral edema associated with risperidone oral solution. A case report and a review of the literature. J Clin Psychopharmacol 2012; 32:128-130.

5. Franco K, Tamburrino M, Campbell N, Pentz J, Evans C. Dopaminergic activity and idiopathic edema. Hosp Community Psychiatry 1991; 42:309-310.

6. Knox ED, Stimmel GL. Clinical review of a long-acting, injectable formulation of risperidone. Clin Ther 2004; 26:19942002.

7. Akdag ST, Fettahoglu EC, Ozatalay E. Pedal edema induced by low-dose risperidone monotheraphy in a child. J Child Adolesc Psychopharmacol 2009; 19:481-482.

8. Kaplan AP, Greaves MW. Angioedema. J Am Acad Dermatol $2005 ; 53: 373-388$

9. Terao T, Kojima H, Eto A. Risperidone and allergic reaction.
J Clin Psychiatry 1998; 59:82-83.

10. Pelizza L. Long-acting risperidone-induced periorbital edema. J Clin Psychopharmacol 2008; 28:709-710.

11. Yang HN, Cheng YM. Peripheral edema associated with risperidone oral solution: a case report and a review of the literature. J Clin Psychopharmacol 2012; 32:128-130.

12. Tunç S, Başbuğ HS. Leg oedema due to low-dose risperidone during maintenance monotherapy of schizophrenia. Psychiatry and Clinical Psychopharmacology 2018; 28:104-106. 